\title{
Domain Superposition Technique for Free Vibration Analysis of Textile Composite Structures
}

DOI: $10.15255 /$ KUI.2015.006 KUI-7/2015

Original scientific paper Received November 17, 2014 Accepted February 3, 2015

\author{
W. G. Jiang, ${ }^{a^{*}}$ C. L. Yu, ${ }^{a}$ Y. X. Zhang, ${ }^{a}$ X. C. Huo, ${ }^{a}$ and L. J. Yan ${ }^{b}$ \\ a School of Mechanical Engineering, Yanshan University \\ 066004 Qinghuangdao, PR China \\ bScience, Technology and Quality Department, \\ Xugong Group Construction Machinery Inc., 221004 Xuzhou, PR China
}

\begin{abstract}
$\|$ Abstract
Textile composites consist of interlaced tows, which are impregnated with a matrix material and then cured. The interlacing of the tows offers the potential for increased through-thickness strength compared to conventional laminated composites. However, one disadvantage of textile composites is the difficulty in predicting their performance due to the complex geometry of their internal architectures. Finite element analysis (FEA) has become an effective means to predict the response of complex textile composite structures. When an attempt is made to perform a conventional FEA, one of the tough issues faced is how to deal with the topologically complex internal geometries. To overcome this difficult issue, a domain superposition technique (DST) has been proposed to implement free vibration analysis of woven composite structures. The significant advantage of the DST over traditional FEA is that it does not need to directly deal with the likely degenerated resin-rich region, thus the DST model is much easier to establish. Numerical results show that DST predictions correlate excellently with traditional FEAs.
\end{abstract}

$\|$ Keywords

Woven composites, domain superposition technique, finite element analysis, dynamic analysis, natural frequency

\section{Introduction}

Textile composites made of resin-infiltrated textile with various architectures, such as $2 \mathrm{D} / 3 \mathrm{D}$ woven fabric, $2 \mathrm{D} / 3 \mathrm{D}$ braiding, knitting, and stitching, have attracted growing interest due to their excellent potential for shaping, light weight, and other attractive properties. They are being widely used as structural components in aerospace, automotive, marine, civil, chemical processing equipment, sporting, land transportation and leisure sectors. ${ }^{1-4}$

The mechanical performance of composites can be evaluated through either experimentation, which is an expensive method, or through a predictive modelling approach, which is an inexpensive alternative. Finite element analysis (FEA) has become an effective modelling means to predict the complex response of composite structures. When an attempt is made to perform a conventional finite element analysis, one of the tough issues faced is how to deal with the topologically complex internal geometries which are inherent in the textile composites. The complex internal reinforcement architectures of the textile composites often lead to the presence of extremely narrow multiconnected matrix regions. It is common knowledge that discretization of the material geometry into finite element mesh is a basic requirement for performing FEA. Unfortunately, it is generally very hard to establish good quality finite element meshes over the degenerated regions. To overcome this

*Corresponding author: Prof. Wenguang Jiang

e-mail: wgj@ysu.edu.cn difficulty, a domain superposition technique (DST) which can easily overcome this difficult issue and realize fast implementation of FEA of textile composites was proposed by the first author. ${ }^{5}$ The procedures for performing both linear and nonlinear static analyses of textile composites were proposed and successfully implemented by the first author and co-workers ${ }^{5-7}$ and was also recently discussed by Tabatabaei et al. ${ }^{8}$ In this paper, the methodology of the DST is further extended to render it possible to perform natural frequency analyses of textile composite structures fully considering the complex internal interlacing textile architecture.

\section{Domain Superposition Technique (DST)}

The concept of DST can be schematically illustrated as in Fig. $1 .^{7}$ In contrast to conventional FEAs which model explicitly the reinforcement domain $\Omega 2$ and the likely degenerated matrix domain $\Omega 1$ which are conjugate to each other (refer to Fig. 1), DST models the reinforcement domain $\Omega 2$, and the global domain $\Omega=\Omega 1 \cup \Omega 2$, both of which are generally non-degenerated (Figs. $1 \mathrm{~b}$ and $1 \mathrm{c}$ ) and can be easily discretized using conventional solid elements. The implementation of DST requires two essential technical strategies. The first is the stiffness matching technique; the second is the establishment of the deformation coupling relationships between the local domain $\Omega 2$ and the 


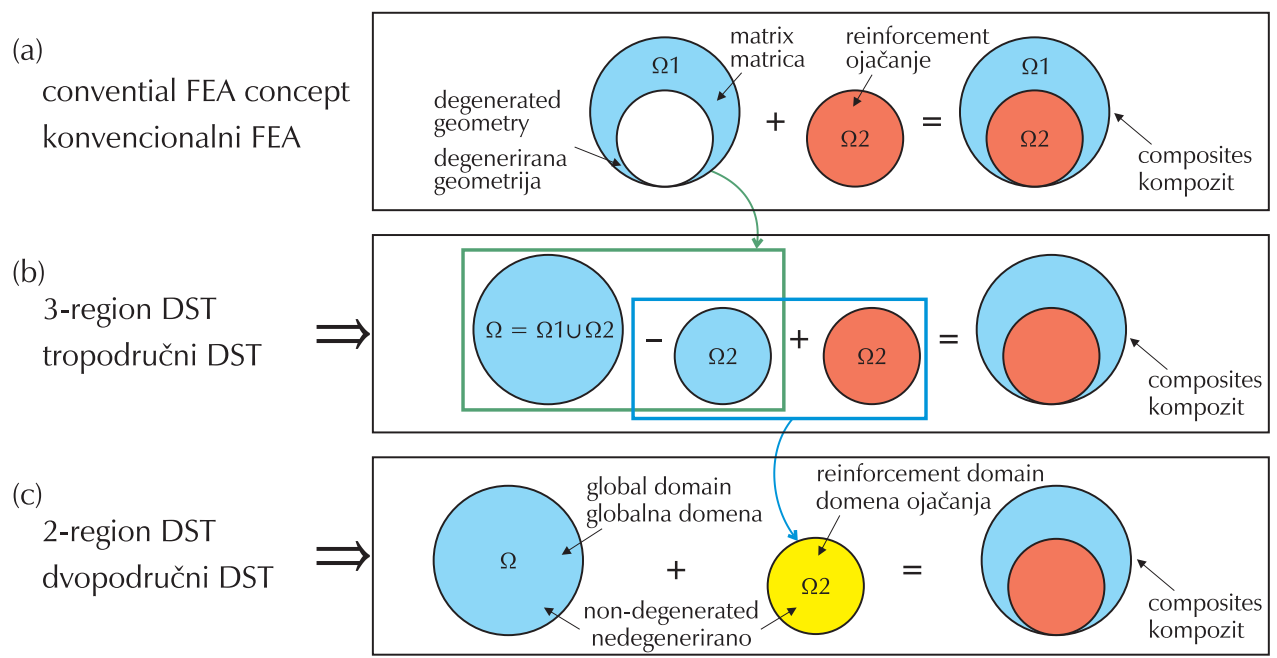

Fig. 1 - Schematic comparisons between conventional FEA and DST $^{7}$

Slika 1 - Shematske usporedbe između konvencionalnog FEA i DST-a ${ }^{7}$

global domains $\Omega$ to ensure that the overlapping regions can deform together when loaded. The correct implementation of these two techniques can ensure that the model works as the actual composite system does.

In general, there are two convenient ways to realizing the material matching requirement, namely, 3-region DST and 2-region DST, respectively. For 3-region DST (Fig. 1b), three sets of geometric domains are involved in this superposition system, i.e., the global geometric domain $\Omega$ using matrix material model, and the two identical duplicate reinforcement geometric domains $\Omega 2$ using different "functional materials". One of the duplicate domains uses "negative matrix material", and the other uses actual reinforcement phase of material property. When the domain $\Omega 2$ with "negative" matrix material is superimposed into the global domain with matrix material, this effectively creates "holes" in the global domain. The subsequential superposition of the second $\Omega 2$ domain with the reinforcement material in the system will function just like filling the "holes" with the reinforcement to accomplish the final composite material system modelled. Since the duplicate reinforcement geometric domains occupy exactly the same space, duplicate FE meshes sharing the same sets of nodal locations can be conveniently used to create the corresponding FE meshes. Furthermore, the duplicate meshes can be merged into one, and consequently a new artificial "material model" must be formulated and implemented to consider the combined effect of the superposition of the "negative" matrix material and the reinforcement material. This leads to an alternative way of realizing the DST, i.e., the 2-region DST as illustrated in Fig. 1c. It is obvious that 3-region DST and 2-region DST are alternative ways of implementing the same technique. For nonlinear analysis, the 3-region DST is more convenient to realize than the 2-region DST.

When implementing DST, then geometric domains are all meshed with solid elements and the elements should be assigned with the correct material properties as discussed above. Coupling equations (CEs) of degrees of freedom (DOFs) between the local meshes of domain $\Omega 2$ and the global mesh of domain $\Omega$ must then be established to ensure that the coincident points between the two domains can have the same displacement during deformation. This is the deformation continuity/compatibility condition of implementing DST, which must be correctly dealt with.

For the sake of easy implementation, the slope discontinuity of deformation field across the material phase boundaries is not treated elaborately in the current DST proposed. Thus, there exist local error bands at the material phase interfaces in current DST models. As a consequence of this, the macroscopic elastic moduli predicted by DST are slightly higher than conventional FEA when a similar degree of mesh refinement is used. These local error bands can be reduced when the FE mesh is further refined. Despite this drawback, the method is still favourable considering its significant merits. This is especially true for natural frequency analyses as the local effects can have little impact on low global frequencies of the global structure.

\section{Numerical Analysis}

Free vibration analysis of textile composite structure using the DST proposed has been implemented in ANSYS finite element analysis software. For free vibration finite element analysis, we can obtain the eigenvalue expression $\mathrm{as}^{9}$

$$
\left(\boldsymbol{K}-\omega^{2} \boldsymbol{M}\right) \phi=0,
$$

where $\boldsymbol{K}$ is the structural stiffness matrix, $\boldsymbol{M}$ is the structure mass matrix, $\omega$ is the frequency (eigenvalue), and $\phi$ an eigenvector containing the free vibration mode. The subspace iteration procedure is used to solve the natural frequency and the eigenvectors. 
A plain-weave woven composite material is used to build all the validation numerical examples presented in this paper. The material consists of repetitive unit cells (RUC). The geometry of these plain-weave composite RUCs is given in Fig. 2. An isotropic elastic material model is used for the matrix material (resin-rich region), and an orthotropic elastic model is used for the actual reinforcement tows. The material elastic constants used for the numerical analyses are $E=3.5 \mathrm{GPa}$ and $v=0.35$ for the matrix material, and $E_{1}=1.38 \cdot 10^{2} \mathrm{GPa}, E_{2}=E_{3}=9 \mathrm{GPa}, v_{12}=v_{13}=v_{23}=0.3$, and $G_{12}=G_{13}=G_{23}=6.9 \mathrm{GPa}$ for the tows (the cured impregnated fibre bundle, i.e., the reinforcement phase material). The densities are $\rho_{\text {matrix }}=1.25 \cdot 10^{3} \mathrm{~kg} \mathrm{~m}^{-3}$ and $\rho_{\text {reinforcement }}=1.55 \cdot 10^{3} \mathrm{~kg} \mathrm{~m}^{-3}$ for the matrix material and the reinforcement tows respectively.

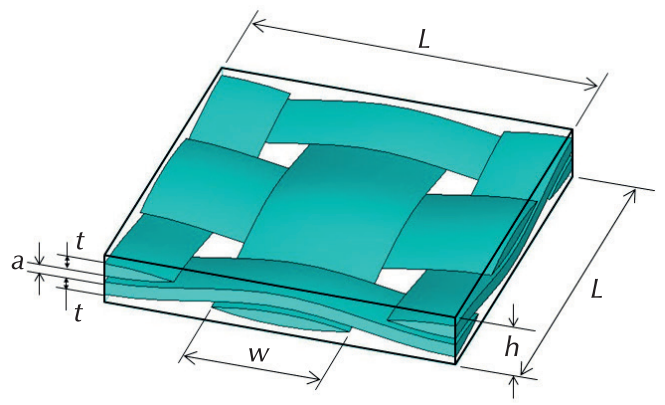

Fig. 2 - Geometry of the repetitive unit cell (RUC) within the woven composite plate analysed. $L=1.68 \mathrm{~mm}, W=$ $0.66 \mathrm{~mm}, h=0.145 \mathrm{~mm}, t=0.66 \mathrm{~mm} ; a=0$ for realistic case, or $a=1 / 10 t$ for closer comparison with conventional FEA.

Slika 2 - Geometrija ponavljajuće jedinične ćelije (RUC) unutar analizirane tkane kompozitne ploče. $L=1,68 \mathrm{~mm}$, $W=0,66 \mathrm{~mm}, h=0,145 \mathrm{~mm}, t=0,66 \mathrm{~mm} ; a=0$ za realne slučajeve ili $a=1 / 10 t$ za bolju usporedbu $\mathrm{s}$ FEA-om.

The first illustrative example is the analysis of a micro-cantilever plain-weave composite beam. The beam consists of three complete RUCs. The geometry of the beam is given in Fig. 3. For validation purposes, both DST and conventional finite element analysis (FEA) were performed.

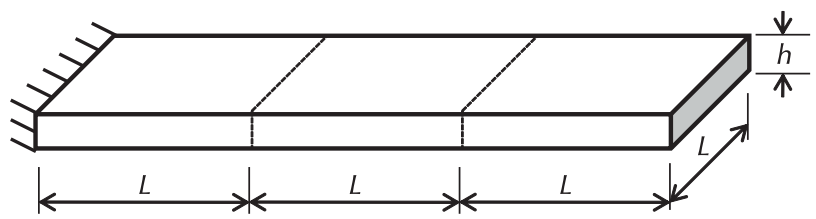

Fig. 3 - Geometry of the micro-cantilever composite beam consisting of three plain-weave RUCs

Slika 3 - Geometrija mikrokogrednog kompozitnog svežnja koji se sastoji od tri ponavljajuće jedinične ćelije u platnenom vezu

For woven composites, the reinforcement tows spanning along the longitudinal direction are usually called the warp tows, and the reinforcement tows along the transverse direction are called the weft tows. The warp tows and the weft tows should touch at tow crossovers for a realistic composite material, i.e. $a=0$, refer to Fig. 2. It would be extremely difficult to build a proper FE mesh for this case with touching tows at the crossover when performing a conventional FEA. For the sake of easy generation of the conventional FE meshes, it is common practice to add an arbitrarily artificial small resin gap between the crossing tows in the geometric model. For example, a small gap $a=$ $1 / 10 t$ is used to establish the geometry for both conventional FEA and DST analyses.

Both the reinforcement tow domain and the global domain of all these DST models could be easily discretized using 8-noded brick elements. A DST finite element model with very coarse mesh is given in Fig. 4. It is suggested that the elements used for the reinforcement phase should be roughly similar or smaller in size than that of the global elements where they reside when preparing the DST meshes. The parameters of all the DST finite element meshes for the analyses of the beam problem are given in Table 1. Compared to DST models, it would be very difficult to establish FE meshes using brick elements for conventional FEA models. Instead, 10-noded tetrahedral elements were used to discretize the comparison conventional FEA models. A comparison conventional finite element mesh with quite fine mesh density is given in Fig. 5. The parameters of the comparison conventional finite element meshes are given in Table 2. Each node of all the solid elements used for both DST and the comparison FEA has three translational DOFs, i.e. translations in $x, y$, and $z$ directions.

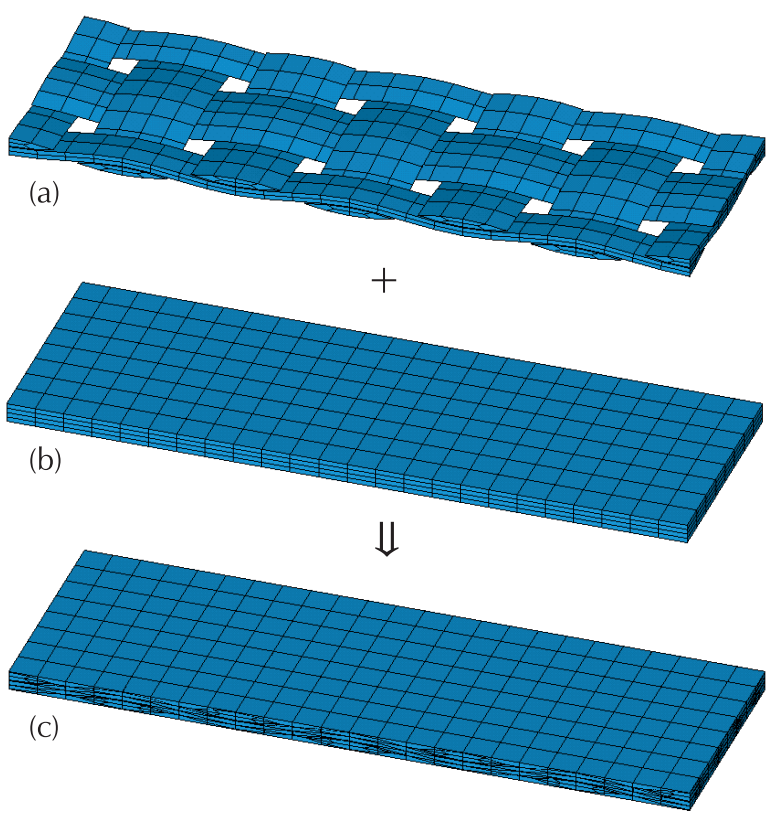

Fig. 4 - DST finite element meshes for the beam problem: (a) tow meshes, (b) global mesh, and (c) superimposed mesh for DST analysis

Slika 4 - Mreže konačnih elemenata DST-a u rješavanju problema svežnjeva: (a) mreža vlakana, (b) globalna mreža i (c) superponirana mreža za DST-analizu 


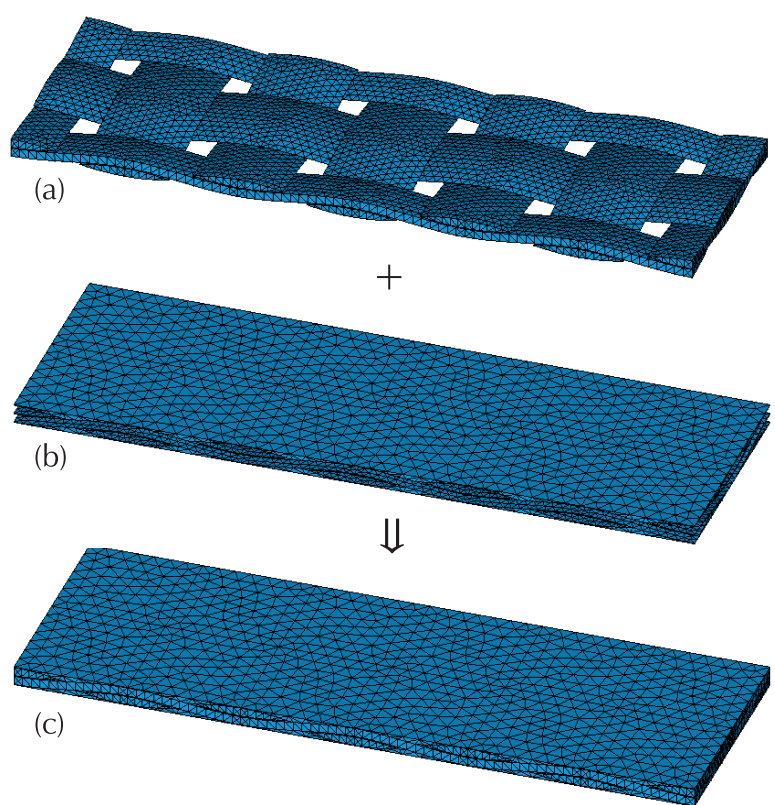

Fig. 5 - Conventional finite element meshes for the cantilever beam problem: (a) tow meshes, (b) matrix meshes, and (c) analysis mesh containing all tow meshes and matrix meshes

Slika 5 - Problem grednih snopova u rješavanju problema grednih svežnjeva: (a) mreže vlakana, (b) matrične mreže i (c) analitička mreža sa svim mrežama vlakana i matričnim mrežama
Modal analyses of the micro-cantilever beam using both DST and conventional FEA models with different levels of refinement have been carried out. The numerical results show that vibration mode shapes correlate very well for all these analyses. The first six mode shapes predicted using the very coarse mesh DST and the fine mesh FEA are compared in Fig. 6. The first six fundamental natural frequencies for all the analyses conducted are compared in Fig. 7. It can be seen from this figure that, as mesh density increases, the natural frequencies predicted using both DST and conventional FEA converge well. The DST predictions are slightly higher than those predicted by conventional FEAs. It is worth mentioning that even using quite coarse mesh, DST could still produce quite accurate predicts. This indicates that it is practical using DST to perform modal analyses of textile composite structures fully considering the complex internal textile architectures. This will be demonstrated in the next numerical example.

The second illustrative example is the analysis of a plainweave composite plate. The plate consists of an array of $10 \times 10 \times 1$ plain-weave RUCs, i.e., a total of 100 RUCs. The finite element meshes used for DST analyses are given in Fig. 9. The number of elements used for the tow meshes are 19 200. The number of elements used for the global domain are $80 \times 80 \times 4=25600$. The total number of nodes of the entire DST model is 68 931. The degree of mesh refinement is the same as the very coarse meshes used in the first numerical example (refer to Fig. 4). All four

Table 1 - Parameters of DST finite element meshes for analysis of the cantilever beam problem

Tablica 1 - Parametri DST-mreže konačnih elemenata za analizu problema grednih svežnjeva

\begin{tabular}{|c|c|c|c|c|c|c|}
\hline $\begin{array}{l}\text { Model } \\
\text { No. } \\
\text { Model br. }\end{array}$ & $\begin{array}{l}\text { Mesh } \\
\text { density } \\
\text { Mrežna } \\
\text { gustoća }\end{array}$ & $\begin{array}{l}\text { Element } \\
\text { type } \\
\text { Vrsta } \\
\text { elementa }\end{array}$ & $\begin{array}{l}\text { No. of nodes } \\
\text { for tows } \\
\text { Broj čvorova } \\
\text { vlakana }\end{array}$ & $\begin{array}{l}\text { No. of nodes } \\
\text { for global domain } \\
\text { Broj čvorova } \\
\text { u globalnoj domeni }\end{array}$ & $\begin{array}{l}\text { No. of elements } \\
\text { for tows } \\
\text { Broj elemenata } \\
\text { vlakana }\end{array}$ & $\begin{array}{l}\text { No. of elements } \\
\text { for global domain } \\
\text { Broj elemenata } \\
\text { u globalnoj domeni }\end{array}$ \\
\hline 1 & $\begin{array}{l}\text { very coarse } \\
\text { vrlo gruba }\end{array}$ & $\begin{array}{l}\text { 8-noded } \\
\text { brick }\end{array}$ & 1246 & 1125 & 576 & 768 \\
\hline 2 & $\begin{array}{l}\text { coarse } \\
\text { gruba }\end{array}$ & $\begin{array}{l}\text { 8-noded } \\
\text { brick }\end{array}$ & 6930 & 7497 & 4608 & 61442 \\
\hline 3 & $\begin{array}{l}\text { intermediate } \\
\text { srednja }\end{array}$ & $\begin{array}{l}\text { 8-noded } \\
\text { brick }\end{array}$ & 20518 & 23725 & 15552 & 20736 \\
\hline
\end{tabular}

Table 2 - Parameters of conventional FEA meshes for analysis of the cantilever beam problem

Tablica 2 - Parametri konvencionalnih FEA-mreža za analizu problema grednih svežnjeva

\begin{tabular}{|c|c|c|c|c|c|c|}
\hline $\begin{array}{l}\text { Model No. } \\
\text { Model br. }\end{array}$ & $\begin{array}{l}\text { Mesh density } \\
\text { Mrežna gustoća }\end{array}$ & $\begin{array}{l}\text { Element } \\
\text { type } \\
\text { Vrsta } \\
\text { elementa }\end{array}$ & $\begin{array}{l}\text { No. of nodes } \\
\text { for tows } \\
\text { Broj čvorova } \\
\text { vlakana }\end{array}$ & $\begin{array}{l}\text { No. of nodes } \\
\text { for matrix domain } \\
\text { Broj čvorova } \\
\text { u matričnoj domeni }\end{array}$ & $\begin{array}{l}\text { No. of elements } \\
\text { for tows } \\
\text { Broj elemenata } \\
\text { vlakana }\end{array}$ & $\begin{array}{l}\text { No. of elements for } \\
\text { matrix domain } \\
\text { Broj elemenata } \\
\text { u matričnoj domeni }\end{array}$ \\
\hline 4 & $\begin{array}{l}\text { fine } \\
\text { fina }\end{array}$ & $\begin{array}{l}\text { 10-noded } \\
\text { tetrahedral }\end{array}$ & 48926 & 61121 & 23136 & 30360 \\
\hline 5 & $\begin{array}{l}\text { very fine } \\
\text { vrlo fina }\end{array}$ & $\begin{array}{l}\text { 10-noded } \\
\text { tetrahedral }\end{array}$ & 87018 & 144057 & 42360 & 72888 \\
\hline
\end{tabular}




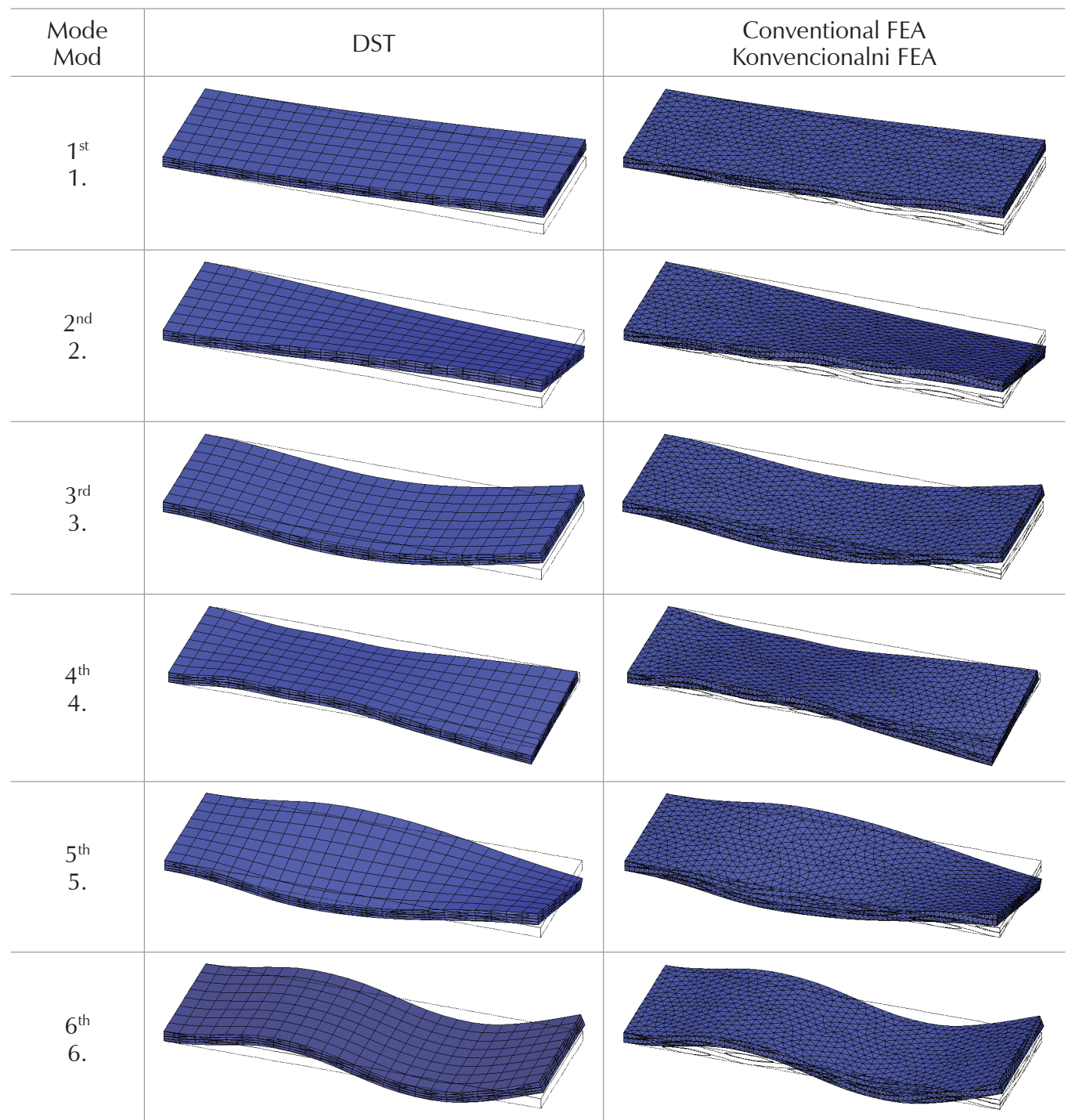

Fig. 6 - Comparison of the fundamental mode shapes predicted by DST and conventional FEA for the cantilever beam problem

Slika 6 - Usporedba osnovnih modova oblika predviđenih DST-om i konvencionalnim FEA-om za problem konzolnih snopova

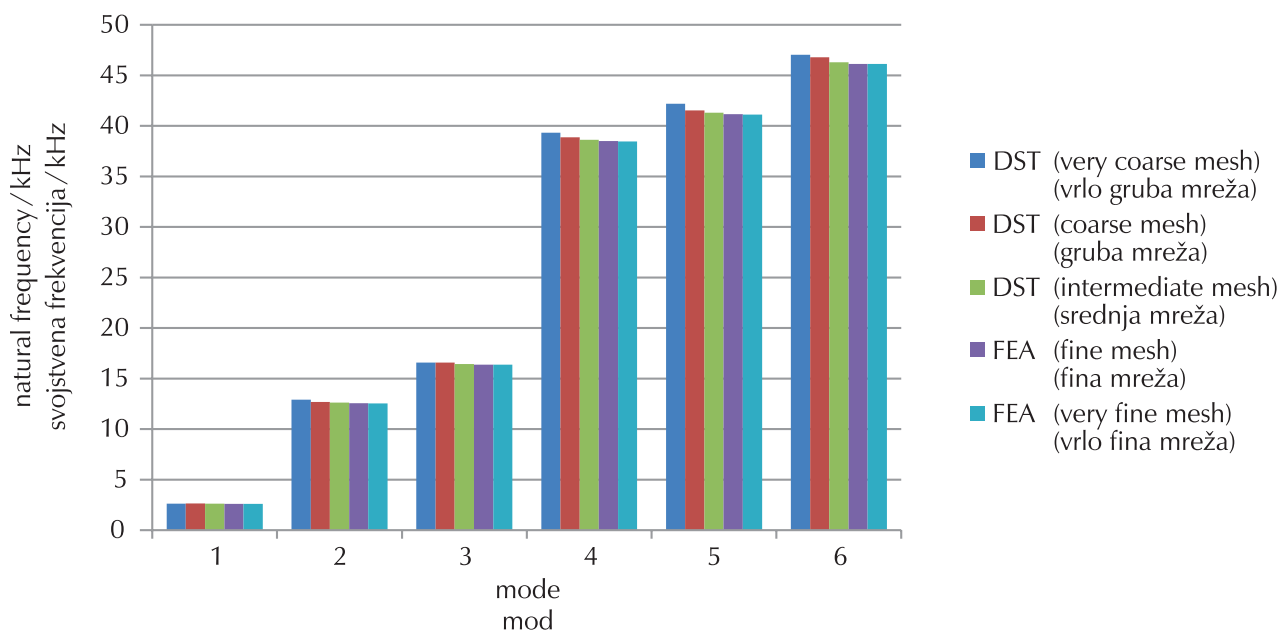

Fig. 7 - Comparison of the first six fundamental natural frequencies predicted using both DST and conventional FEA for the cantilever beam problem

Slika 7 - Usporedba prvih šest temeljnih svojstvenih frekvencija predviđenih primjenom DST-a i konvencionalnog FEA-a u problemu grednih svežnjeva 
edges of the plate analysed are rigidly clamped. This is done by constraining all degrees of freedom of the nodes on the four plate edge boundaries of the global mesh. Coupling equations are established between the degrees of freedom of the tow meshes and the global meshes, as discussed in Section 3.1. All geometric parameters of the RUCs used in the example are the same as used in the previous example except that the gaps between the interlacing tows is set to zero $(a=0)$ in order to simulate a more realistic woven geometry (refer to Fig. 2). It would be extremely difficult to build a proper FEA mesh for this case with touching tows at the crossover using conventional FEA. However, this is no longer an issue for DST analyses. The first 15 mode shapes predicted using the DST are given in Fig. 8. For clear visualization purposes, only the reinforcement tows are plotted and the matrix phase of material is not shown in the figure. It can be seen that the major types of the low frequency vibration modes are out-of-plane vibrations. The natural frequencies predicted are given in Fig. 10. As the natural frequency increases, the mode shape becomes more complex. All mode shapes show some kind of symmetry with respect to the symmetric axis due to the symmetric features of the structure. From these figures, we can also observe that there exist several duplicate pairs of mode shapes with nearly the same natural frequencies, for example, between modes 2 and 3 , between modes 5 and 6 , and between modes 7 and 8, etc. This is also due to the symmetric features of both the geometry and the boundary condition.

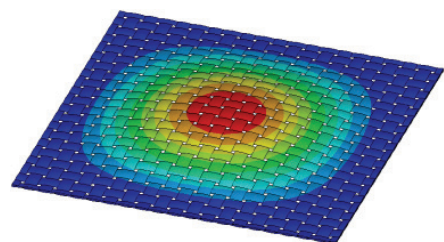

$1^{\text {st }}$ mode / 1. $\bmod$

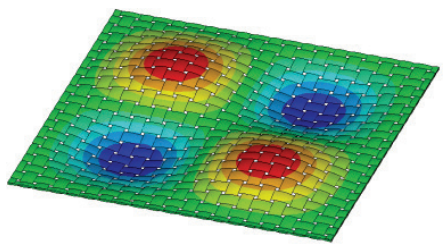

$4^{\text {th }}$ mode $/ 4$. mod

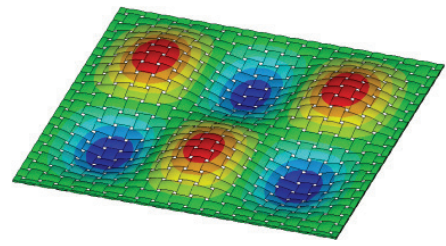

$7^{\text {th }}$ mode / 7. $\bmod$

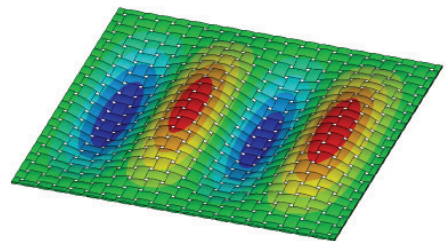

$10^{\text {th }}$ mode $/ 10 . \mathrm{mod}$

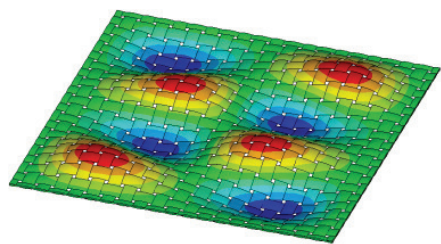

$13^{\text {th }}$ mode $/ 13$. mod

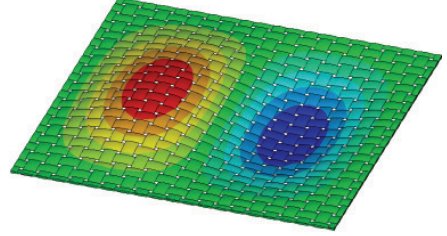

$2^{\text {nd }}$ mode / 2. mod

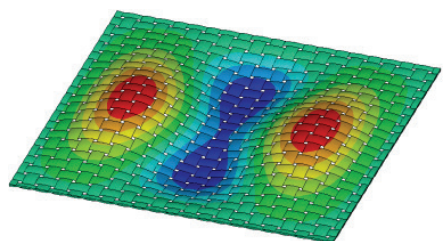

$5^{\text {th }}$ mode / 5. mod

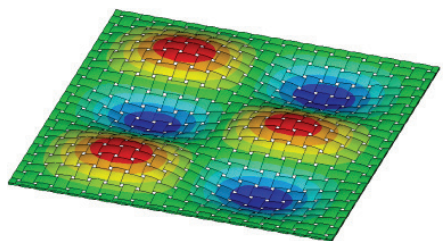

$8^{\text {th }}$ mode / 8. $\bmod$

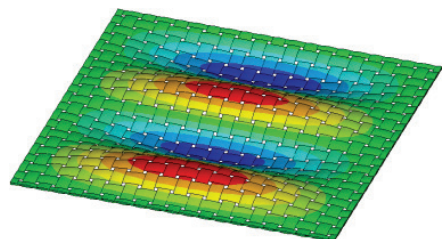

$11^{\text {th }}$ mode $/ 11 . \bmod$

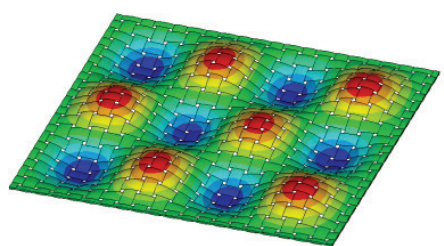

$14^{\text {th }}$ mode $/ 14 . \bmod$

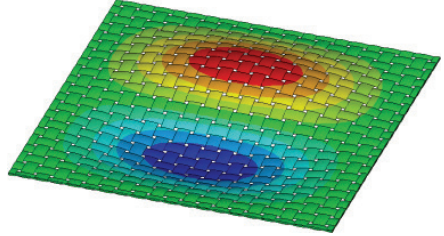

$3^{\text {rd }}$ mode / 3. mod

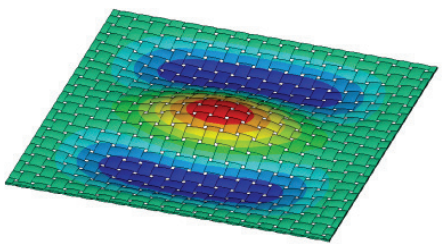

$6^{\text {th }}$ mode $/ 6 . \bmod$

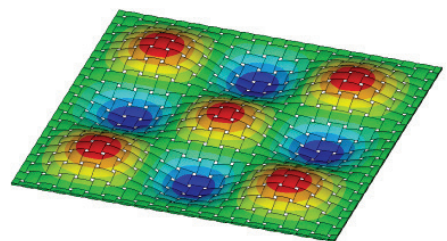

$9^{\text {th }}$ mode $/ 9 . \bmod$

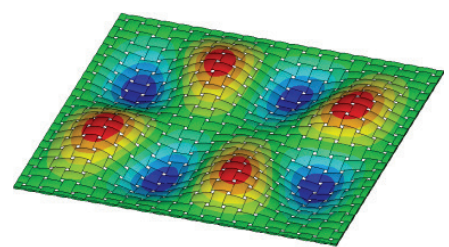

$12^{\text {th }}$ mode $/ 12 . \bmod$

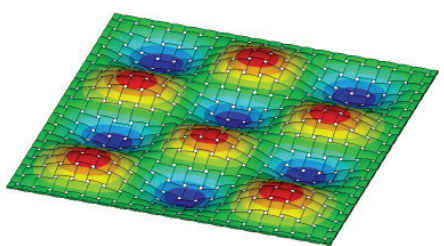

$15^{\text {th }}$ mode $/ 15 . \bmod$

Fig. 8 - The first fifteen fundamental vibration modes predicted using the DST for the clamped woven composite plate problem

Slika 8 - Prvih petnaest osnovnih vibracijskih modova predviđenih s pomoću DST-a za učvršćenu tkanu kompozitnu ploču 


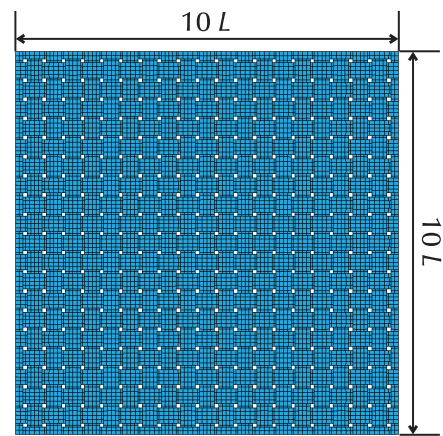

(a)

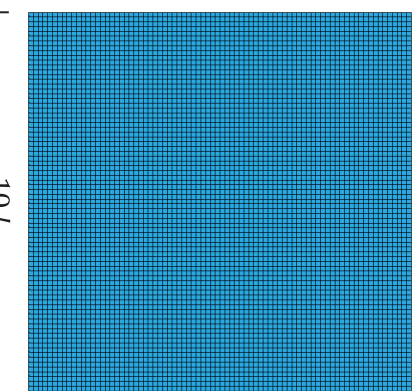

(b)
Fig. 9 - DST finite element meshes for the woven composite plate problem: (a) tow mesh, (b) global mesh

Slika 9 - Mreže konačnih elemenata DST-a u rješavanju problema tkane kompozitne ploče: (a) mreža vlakana, (b) globalna mreža

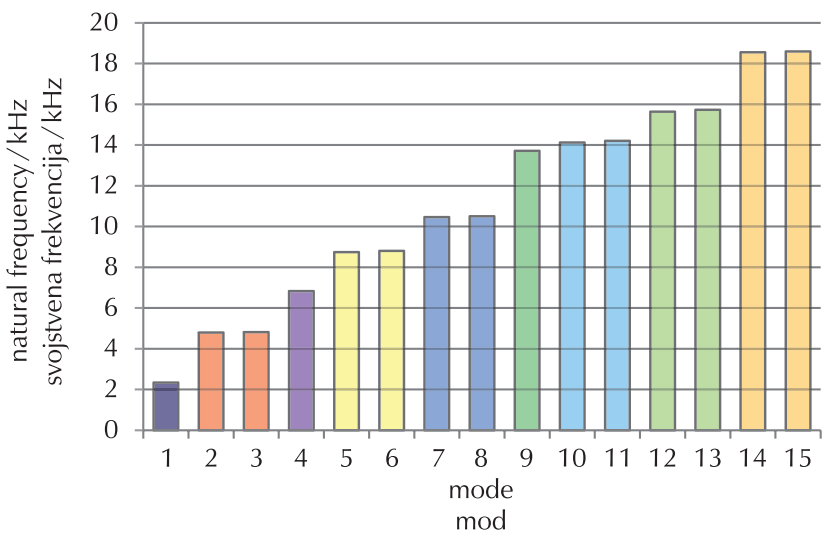

Fig. 10 - The first fifteen fundamental natural frequencies predicted using the DST for the clamped woven composite plate problem

Slika 10 - Prvih petnaest osnovnih vibracijskih modova predviđenih s pomoću DST-a za učvršćenu tkanu kompozitnu ploču

\section{Conclusions}

The domain superposition technique (DST) has been successfully implemented to perform free vibration analyses of complex textile composite material structures. Numerical results show that DST predictions are in good agreement with traditional finite element analyses in terms of both vibration modes and natural frequencies. DST analyses independently discretize the reinforcement domain and the global domain which are generally both non-degenerated using the traditional solid elements. This can be much easier to implement than the conventional finite element analyses which require discretization of both the conjugate reinforcement phase and the likely degenerated matrix phase with proper matching interface between them. The DST can be easily implemented within the framework of traditional finite element software environment, and the model size could be significantly smaller than those of traditional finite analyses.

\section{ACKNOWLEDGEMENT}

This work is funded by Hebei Research Funding for Outstanding Returning Overseas Researchers (No. 20100707), and the Natural Science Foundation of Hebei Province, P.R. China (No. E2015203160)

\section{List of symbols and abbreviations Popis simbola i kratica}

\section{E}$$
\begin{array}{ll}
E_{1}, E_{2}, E_{3} & - \text { Young's modulus of the tows, GPa } \\
& - \text { Youngov modul vlakna, GPa }
\end{array}
$$

$G_{12}, G_{13}, G_{23}$ - shear modulus of the tows, GPa

- modul smičnosti vlakana, GPa$$
h
$$

K

$L$$$
v_{12}, v_{13}, v_{23}
$$

$\rho_{\text {matrix }}$

\section{$\rho$}

M
t
W
v

\section{CE}

\section{DOF}

\section{DST}

$\mathrm{FE}$
Fes$$
\text { . }
$$

\section{RuC}
- finite element analysis
- analiza konačnih elemenata
- repetitive unit cell
- ponavljajuća jedinična ćelija
- global domain in DST model
- globalna domena u modelu DST

- height of the repetitive unit cell, mm

- visina ponavljajuće jedinične ćelije, mm

- structural stiffness matrix

- matrica strukturne krutosti

- length of the repetitive unit cell, mm

- duljina ponavljajuće jedinične ćelije, mm

- structure mass matrix

- matrica strukturne mase

- height of the tows, $\mathrm{mm}$

- visina vlakna, mm

- width of the tows, $\mathrm{mm}$

- širina vlakna, mm

- matrix material Poisson's ratio

- Poissonov koeficijent materijala matrice

- Poisson's ratio of the tows

- Poissonovi koeficijenti vlakana

- matrix material density, $\mathrm{kg} \mathrm{m}^{-3}$

- gustoća materijala matrice, $\mathrm{kg} \mathrm{m}^{-3}$

- density of the reinforcement tows, $\mathrm{kg} \mathrm{m}^{-3}$

- gustoća vlakana ojačanja, $\mathrm{kg} \mathrm{m}^{-3}$
- eigenvector containing the free vibration mode

- svojstveni vektor koji sadrži slobodne načine vibracija

- eigenfrequency

- svojstvena frekvencija

- coupling equation

- jednadžba sprege

- degrees of freedom

- stupnjevi slobode

- domain superposition technique

- metoda superpozicije domena

- finite element

- konačni element

interlacing tows, $\mathrm{mm}$

modulus of the matrix material, GPa 
$\Omega 1$ - degenerated matrix domain

- degenerirana domena matrice

$\Omega 2$

- reinforcement domain

- domena ojačanja

\section{References}

\section{Literatura}

1. C. Soutis, Fibre reinforced composites in aircraft construction, Prog. Aerosp. Sci. 41 (2005) 43-151, doi: http://dx.doi. org/10.1016/j.paerosci.2005.02.004.

2. A. P. Mouritz, M. K. Bannister, P. J. Falzon, K. H. Leong, Review of applications for advanced three-dimensional fibre textile composites, Compos. Part A-Appl. S. 30 (1999) 1445-1461, doi: http://dx.doi.org/10.1016/S1359-835X(99)00034-2.

3. M. Ansar, X. W. Wang, C. W. Zhou, Modeling strategies of 3D woven composites: A review, Compos. Struct. 9 (2011) 1947-1963, doi: http://dx.doi.org/10.1016/j.compstruct.2011.03.010.

4. S. D. Green, A. C. Long, B. S. F. El Said, S. R. Hallett, Nu- merical modelling of 3D woven preform deformations, Compos. Struct. 108 (2014) 747-756, doi: http://dx.doi. org/10.1016/j.compstruct.2013.10.015.

5. W. G. Jiang, A computer and a method of modelling a woven composite material, Int. Pat. 16 Oct 2008; PCT/GB2008/ 000713.

6. W. G. Jiang, S. R. Hallett, M. R. Wisnom, Development of domain superposition technique for the modelling of woven fabric composites, in P. P. Camanho, C. G. Davila, S. T. Pinho and J. J. C. Remmers (ed.), Mechanical Response of Composites. Berlin, Springer, 2008, pp. 281-291, doi: http://dx.doi. org/10.1007/978-1-4020-8584-0_14.

7. W. G. Jiang, Implementation of domain superposition technique for the nonlinear analysis of composite materials, J. Compos. Mater. 47 (2013) 243-249, doi: http://dx.doi. org/10.1177/0021998312439220.

8. S. A. Tabatabaei, S. V. Lomov, I. Verpoest, Assessment of embedded element technique in meso-FE modelling of fibre reinforced composites, Compos. Struct. 107 (2014) 436-446, doi: http://dx.doi.org/10.1016/j.compstruct.2013.08.020.

9. K. J. Bathe, Finite Element Procedures, Prentice-Hall Inc., 1996.

\section{SAŽETAK \\ Metoda superpozicije domena $u$ analizi slobodnih vibracija tekstilnih kompozitnih struktura \\ Wen-Guang Jiang, ${ }^{a^{*}}$ Chun-Lei Yu, ${ }^{a}$ Yong-Xu Zhang, ${ }^{a}$ Xiao-Chun Huo a Li-Juan Yan ${ }^{\text {b }}$}

Tekstilni kompoziti načinjeni su od isprepletenih vlakana koja se impregniraju matričnim materijalom i zatim očvršćuju. Preplitanjem vlakana može se povećati poprečna čvrstoća u usporedbi s konvencionalnim laminarnim kompozitima. Međutim, nedostatak tekstilnih kompozita je teško predviđanje osobina zbog složene geometrije unutarnje građe. Analiza konačnih elemenata (FEA) postala je učinkovito sredstvo za predviđanje ponašanja složenih tekstilnih kompozitnih struktura. Jedan od problema koji se javljaju u primjeni konvencionalne metode konačnih elemenata je topološki kompleksna unutarnja geometrija. Za prevladavanje te poteškoće predlaže se primjena metode superpozicije domena (DST) radi analize vibracija tkanih kompozitnih struktura. Važna prednost DST-a pred tradicionalnim FEA-om jest u tome da nije potrebno izravno se baviti područjem bogatim smolom koje je vjerojatno degenerirano. Numerički rezultati pokazuju da predviđanja DST-a izvrsno koreliraju s tradicionalnim FEA-om.

Ključne riječi

Tkani kompoziti, metoda superpozicije domena, metoda konačnih elemenata, dinamička analiza, svojstvena frekvencija

a School of Mechanical Engineering

Yanshan University

066004 Qinghuangdao

PR China

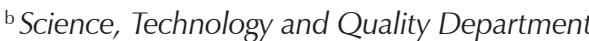

Xugong Group Construction Machinery Inc.

221004 Xuzhou

PR China
Izvorni znanstveni rad Prispjelo 17. studenoga 2014. Prihvaćeno 3. veljače 2015. 